Holland Division

At the annual meeting on June 13 the following officers were elected :

Chairman.-Dr. A. S. Wilson.

Vice-chairman.-Dr. W. O. Nowlan.

Honorary Secretary.-Dr. J. E. Darlow.

Kensington and Hammersmith Division

The annual general meeting was held at St. Mary Abbot's Hospital, Kensington, on April 25. Dr. J. F. L. King took the chair and 19 members were present. The following officers were elected:

Chairman.-Dr. H. S. Pasmore.

Deputy Chairman.-Dr. O. Moses.

Honorary Secretary.-Dr. J. D. W. Whitney.

Honorary Treasurer.-Dr. C. L. Collins.

\section{KeSTEVen Division}

The following officers were elected at the annual meeting:

Chairman.-Dr. I. W. S. Gibb.

Vice-chairman.-Dr. G. B. Pimblett.

Treasurer.-Mr. F. J. Jauch.

\section{MERSEYSIDE BRANCH}

The annual general meeting was held on June 4 on the premises of Messrs. Cadbury Brothers Ltd. at Moreton, Wirral. Ninetyfive members were present. The following officers were elected: President.-Dr. E. A. K. Hoppins.

President-elect, Secretary, and Treasurer.-Dr. V. Cotton Cornwall.

Vice-presidents.-Dr. T. R. Roberton and Dr. N. S. Walls.

Members were entertained to lunch by Messrs. Cadbury Bros. and toured their chocolate and chocolate biscuit factory in the afternoon.

\section{Mombasa Division}

A meeting was held at the Coast General Hospital on May 12. Mr. S. R. Keating took the chair and 18 members were present. Mr. Kirkaldy-Willis gave an address on "Tuberculosis of the Bone."

\section{Newcastle UPON Tyne Division}

The following officers were elected at the annual meeting on May 20:

Chairman.-Dr. R. Wear.

Vice-chairman.-Dr. T. H. Boon.

Honorary Secretary and Treasurer.-Dr. G. W. Anderson.

Honorary Assistant Secretary and Treasurer.-Dr. G. Cormack.

Honorary Students' Secretary.-Mr. Weldon Watts.

\section{North Glamorgan and Brecknock Division}

The annual general meeting was held at the Black Lion Hotel,

Aberdare, on May 21. The following officers were elected:

Chairman-Dr. J. W. R. Battram.

Vice-chairman.-Dr. J. L. Ryce.

Secretary and Treasurer.-Dr. F. J. Doherty.

NORTH STAFFordShiRe Division

At the annual general meeting on May 20 the following officers were elected:

Chairman.-Mr. P. J. M. Kent

Vice-chairman and Secretary.-Dr. J. M. Johnstone.

Joint Secretary.-Dr. W. Livingstone.

Treasurer.-Dr. J. Manuel.

\section{Preston Division}

At the annual general meeting on May 20 the following officers were elected:

Chairman.-Dr. A. L. Williams.

Vice-chairman.-Dr. D. M. Anderson.

Honorary Secretary and Treasurer.-Dr. W. M. Thomas.

A ssistant Bonorary Secretary.-Dr. W. H. Tod.

\section{Reading Drvision}

The following officers have been elected:

Chairman.-Dr. Harley Stevens

Vice-chairman.-Mr. G. L. Bohn.

Honorary Secretary and Treasurer.-Dr. P. W. F. McIlvenna.

\section{Reigate Division}

At the annual general meeting on May 20 the following officers were elected:

Chairman.-Dr. L. A. Gibbons.

Vice-chairman.-Dr. H. S. Atkinson.

Honorary Secretary and Treasurer.-Dr. J. R. Partridge.
St. Pancras Division

The following officers have been elected for 1958-9:

Chairman.-Dr. J. Wigg.

Vice-chairman.-Dr. D. Blend

Honorary Secretary and Treasurer.-Dr. J. Hodson.

SOUTH StafFordshire Division

The following officers have been elected:

Chairman.-Dr. L. B. Paling.

Honorary Secretary and Treasurer.-Dr. H. R. Chapman.

South-west Wales Division

The annual meeting was held on May 4. The following officers were elected:

Chairman.-Dr. D. Gwyn Jones.

Chairman-elect.-Dr. D. F. Lloyd.

Honorary Secretary.-Dr. J. E. Crane.

\section{Swansea Division}

The annual meeting was held on June 5 at the Swansea General Hospital. Dr. H. William Howell was in the chair. The following officers were elected:

Chairman.-Dr. T. Hamilton Anderson.

Vice-chairman.-Dr. Glyn M. Jones.

Senior Secretary and Treasurer.-Dr. T. Oakley Lewis.

Junior Secretary.-Dr. A. M. Revie.

TORQuAY Division

The annual general meeting was held on May 13. The following officers were elected:

Chairman.-Dr. A. Everard.

Vice-chairman.-Mr. J. MacPherson.

Honorary Secretary.-Dr. K. M. Fergusson.

Honorary Treasurer.-Dr. H. W. Thompson.

TYRONE DIVISION

The following officers have been elected for 1958-9:

Chairman.-Dr. J. M. Garvin

Vice-chairman.-Dr. Eileen O'Kane.

Honorary Secretary.-Dr. Knox Henry.

Honorary Treasurer.-Dr. L. A. Lyle.

\section{Wallasey Division}

The following officers have been elected for 1958-9:

Chairman.-Dr. E. A. K. Hoppins.

Vice-chairman.-Dr. M. J. Conlon.

Honorary Secretary.-Dr. D. W. Townley.

Honorary Treasurer.-Dr. A. Colson Hay.

WANDSWORTH DIVISION

At the annual general meeting on Aptil 29 the following officers were elected:

Chairman.-Dr. G. R. Boyes.

Vice-chairman and Honorary Secretary.-Dr. T. J. Lee.

Honorary A ssistant Secretary.-Dr. G. J. R. Clarke.

Honorary Treasurer.-Dr. J. Tudor Lewis.

West SOMERSET Division

The following officers were elected at the annual general meeting :

Chairman.-Dr. T. L. H. Shore

Vice-chairman.-Mr. R. D. Rowlands.

Chairman-elect.-Dr. D. Hague.

Honorary Secretary.-Dr. D. G. Kibblewhite.

Honorary Assistant Secretary.-Dr. L. Fay.

Honorary Treasurer.-Dr. Isabella C. F. Hungerford.

West Sussex Division

At the annual general meeting on May 11 the following officers were elected:

Chairman.-Dr. T. L. Scott.

Vice-chairmen.-Mr. A. G. Ross and Dr. J. Lipsey

Honorary Secretary and Treasurer.-Dr. T. P. Mulcahy. WiGan Division

At the annual general meeting on May 22 the following officers were elected:

Chairman.-Dr. J. E. T. Shirlaw.

Vice-chairman.-Mr. R. L. Hartley.

Honorary Secretary.-Dr. F. G. Ince.

Correction.-The motion by East Denbigh and Flint at the A.R.M., reported as carried under " Compensation at Age of $\mathbf{7 0 "}$ (Supplement, July 26, p. 93), was in fact amended, and the resolution adopted by the meeting should read: "That this Meeting considers that practice compensation should be payable at 65 years of age irrespective of retirement, as well as at retirement or death." 